\title{
A Chemical Synthesis Study Establishes the True Structure of the Potent Anti-Inflammatory Agent Myrsinoic Acid F
}

\author{
Jiri Mikusek, ${ }^{\text {a }}$ Jeremy Nugent, ${ }^{\text {a }}$ Ping Lan, ${ }^{\text {b,c }}$ and Martin G. Banwell,*,a,b \\ ${ }^{a}$ Research School of Chemistry, Institute of Advanced Studies, \\ The Australian National University, Canberra, ACT 2601, Australia \\ ${ }^{b}$ Institute of Advanced and Applied Chemical Synthesis, Jinan University, Zhuhai, \\ 519070, China \\ ${ }^{c}$ Department of Food Science and Engineering, \\ Jinan University, Guangzhou, 510632, China

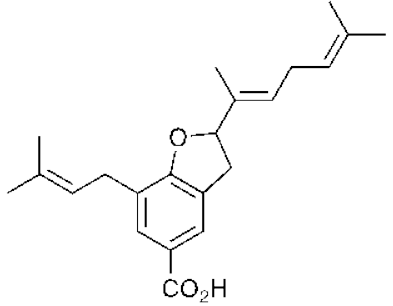 \\ originally proposed structure \\ for myrsinoic acid $\mathrm{F}$

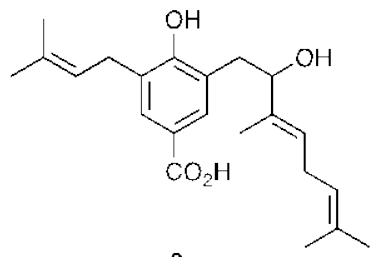 \\ true structure \\ of myrsinoic acid $F$
}

\begin{abstract}
A total synthesis of compound 3 from $p$-bromophenol is reported and thereby establishing that this, rather than its cyclodehydrated counterpart $\mathbf{1}$ (as postulated originally), is the true structure of the natural product myrsinoic acid F. The biological evaluation of compound $\mathbf{3}$ in a mouse-ear edema assay has established that it is significantly more potent anti-inflammatory agent than the NSAID indometacin.
\end{abstract}


In 2002, Hirota and co-workers reported ${ }^{1}$ on the isolation and structural elucidation of a series of anti-inflammatory agents, named the myrsinoic acids, from the fresh leaves and twigs of Myrsine seguinii, a hardwood of the Myrsinaceae family found in various parts of Asia from Myanmar to Japan. The most active of these compounds was myrsinoic acid F (MA-F) and to which structure 1 (Figure 1) was assigned ${ }^{1}$ on the basis of a range of NMR spectroscopic and mass spectrometric studies. This compound and various structurally related co-metabolites have since been encountered in certain other plants found in several parts of the globe and a number of these have been shown to exhibit potentially useful biological properties including selective cytotoxic, antimicrobial and antileishmanial effects. ${ }^{2}$ The anti-inflammatory properties of these compounds may arise through their inhibition of DNA polymerase $\lambda .^{3}$

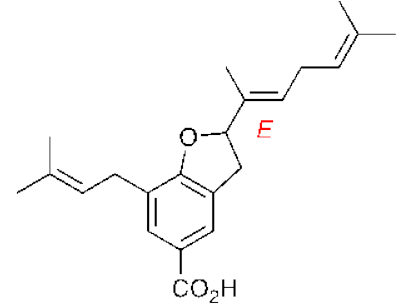

1

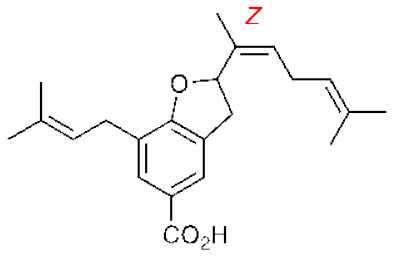

2

Figure 1: The Originally Proposed Structure, 1, of Myrsinoic Acid, its Z-Isomer 2

Recently, we reported ${ }^{4}$ total syntheses of compound $\mathbf{1}$ and its Z-isomer 2. Each of these compounds proved to be a potent anti-inflammatory agent, as determined in a mouse-ear edema assay. However, neither of them corresponds to the structure of MA-F. Clearly, then, the question arises as to the true structure of MA-F. In considering this matter and the similarities of the spectral data for certain open-chain precursors (ie ones lacking the dihydrobenzofuran ring) to compound $\mathbf{1}$ with those reported for the natural product, the possibility arose that the $p$-hydroxybenzoic acid 3 (Figure 2) represents the true structure. It is conceivable that the molecular ion for such a species would not be observed in the electron-impact mass spectrum because of its facile dehydration under the conditions involved and so leading to an erroneous structural assignment. ${ }^{5}$ Interestingly, compound 3 has been reported in the patent literature ${ }^{6}$ as a natural product isolated from the aerial 
parts of the Southern African tree Rapanaea melanophloeos but we have been unable to secure copies of the spectral data for this material. Accordingly, we sought to adapt our syntheses of compounds $\mathbf{1}$ and $\mathbf{2}$ to the preparation of target $\mathbf{3}$ so as to be able to compare the derived spectral data with those reported for MA-F. The outcomes of such studies are reported here together with the results of evaluating the anti-inflammatory properties of compound $\mathbf{3}$ and certain synthetic analogues in a mouse-ear edema assay.

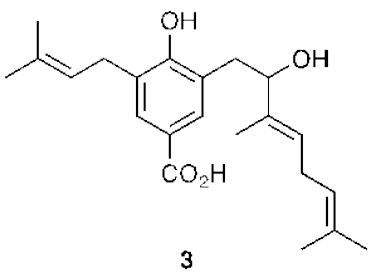

Figure 2: The Revised Structure, 3, Proposed for Myrsinoic Acid F 


\section{RESULTS AND DISCUSSION}

\section{Synthetic Studies}

The successful synthesis of compound $\mathbf{3}$ from $p$-bromophenol traversed the same first two steps used in the preparation of dihydrobenzofuran $\mathbf{1}$ as well as minor variations on the third and fourth ones. ${ }^{4}$ Thus, as shown in Scheme 1 , reaction of $p$-bromophenol (4) with prenyl bromide in the presence of sodium hydride afforded the previously reported, ${ }^{7}$ $C$-alkylated product 5 (64\%). Formylation of product 5 using paraformaldehyde in the presence of triethylamine and magnesium chloride gave compound 6 (68\%) that was itself subject to Wittig olefination using the ylide $\mathrm{Ph}_{3} \mathrm{P}=\mathrm{CH}(\mathrm{OMe})$ in the presence of triethylsilyl chloride (TES-Cl) and potassium tert-butoxide. As a result, the previously unreported enol ether 7 (67\%) was obtained and hydrolysis of this using trifluoroacetic acid (TFA) as catalyst then gave the arylated acetaldehyde 8 in 94\% yield

Scheme 1: The Conversion of p-Bromophenol (4) into into Aryl Acetaldehyde 8.

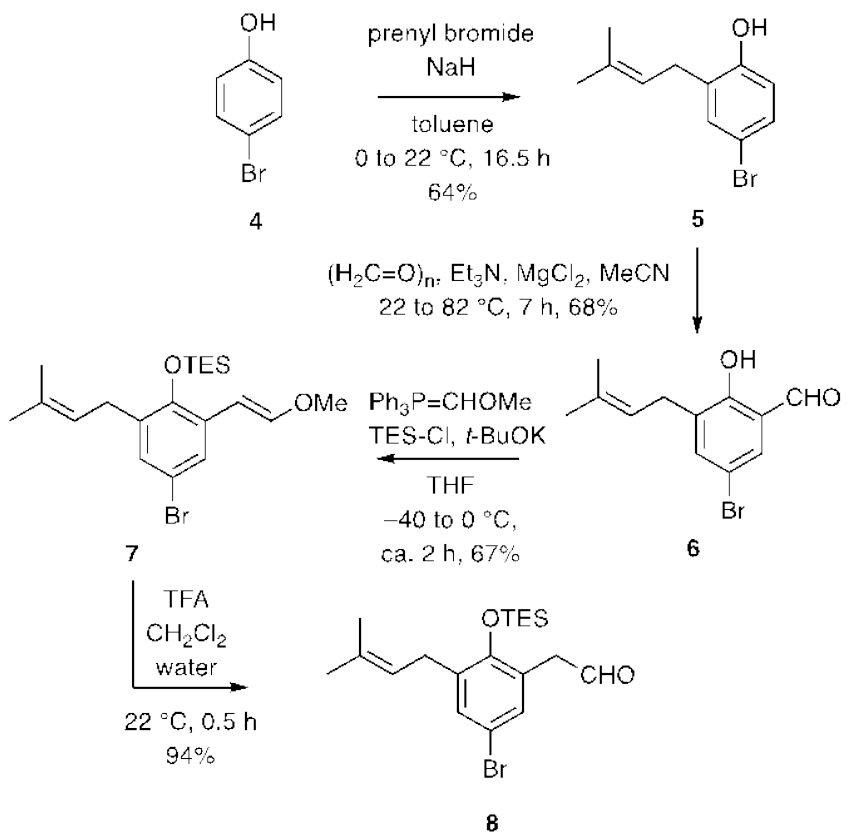

The known alkenyl iodide required for completion of the assembly of the geranyl-type side-chain associated with target $\mathbf{3}$ was synthesized by the more concise and higher yielding route shown in Scheme 2. This exploited, as the key step, the Bond 
modification $^{8}$ of the Shapiro reaction and allowed for the direct introduction of the halogen. Thus, acetone 2,4,6-triisopropylbenzenesulfonylhydrazone $(\mathbf{9})^{4}$ was treated successively with $n$-BuLi then prenyl bromide at -78 to $-60{ }^{\circ} \mathrm{C}$. The alkylated derivative thus obtained was treated in situ, again at at $-78{ }^{\circ} \mathrm{C}$, with a second aliquot of $n$-BuLi and the ensuing anion allowed to warm to $0{ }^{\circ} \mathrm{C}$ at which point gas evolution was observed. Once this had ceased (after ca. $0.5 \mathrm{~h}$ ), the reaction mixture was re-cooled to $-78{ }^{\circ} \mathrm{C}$ before being treated with 1,2-di-iodoethane. Quenching the reaction mixture with sodium thiosulfate followed by conventional workup then gave the light-sensitive iodide $\mathbf{1 0}$ in 91\% yield. This material was identical in all respects with a sample prepared by the earlier route. ${ }^{4}$

Scheme 2: A Direct Synthesis of Alkenyl Iodide 10.

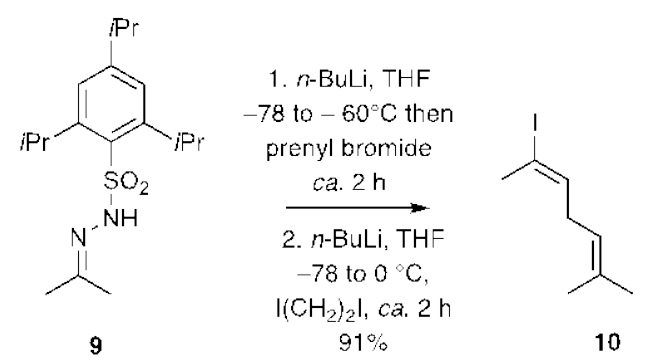

As shown in Scheme 3, the conversion of compound 8 into target $\mathbf{3}$ proved to be a relatively straightforward process. Thus, the alkenyllithium obtained by treating an ethereal solution of iodide $\mathbf{1 0}^{4}$ with tert-butyllithium was treated, in situ, with aldehyde $\mathbf{8}$ and thus affording, after aqueous work-up, the allylic alcohol 11 in 64\% yield. Reaction of the last compound with TES-Cl in the presence of imidazole afforded the bis-ether 12 (95\%) and this served as the immediate precursor to target 3. So, by simply treating a THF solution of compound 12 maintained at $-78{ }^{\circ} \mathrm{C}$ with $t$-butyllithium the anticipated metal-for-bromine exchange took place and the ensuing aryllithium was trapped with gaseous and dried carbon dioxide. The resulting mixture was treated with aqueous acetic acid acid and heated at $50{ }^{\circ} \mathrm{C}$ for $36 \mathrm{~h}$. After cooling, extractive workup and flash column chromatography, carboxylic acid 3 was obtained in 75\% yield as a clear, light-yellow oil. 
Scheme 3: The Conversion of Compound 8 into the True Structure, 3, of Myrsinoic Acid F.

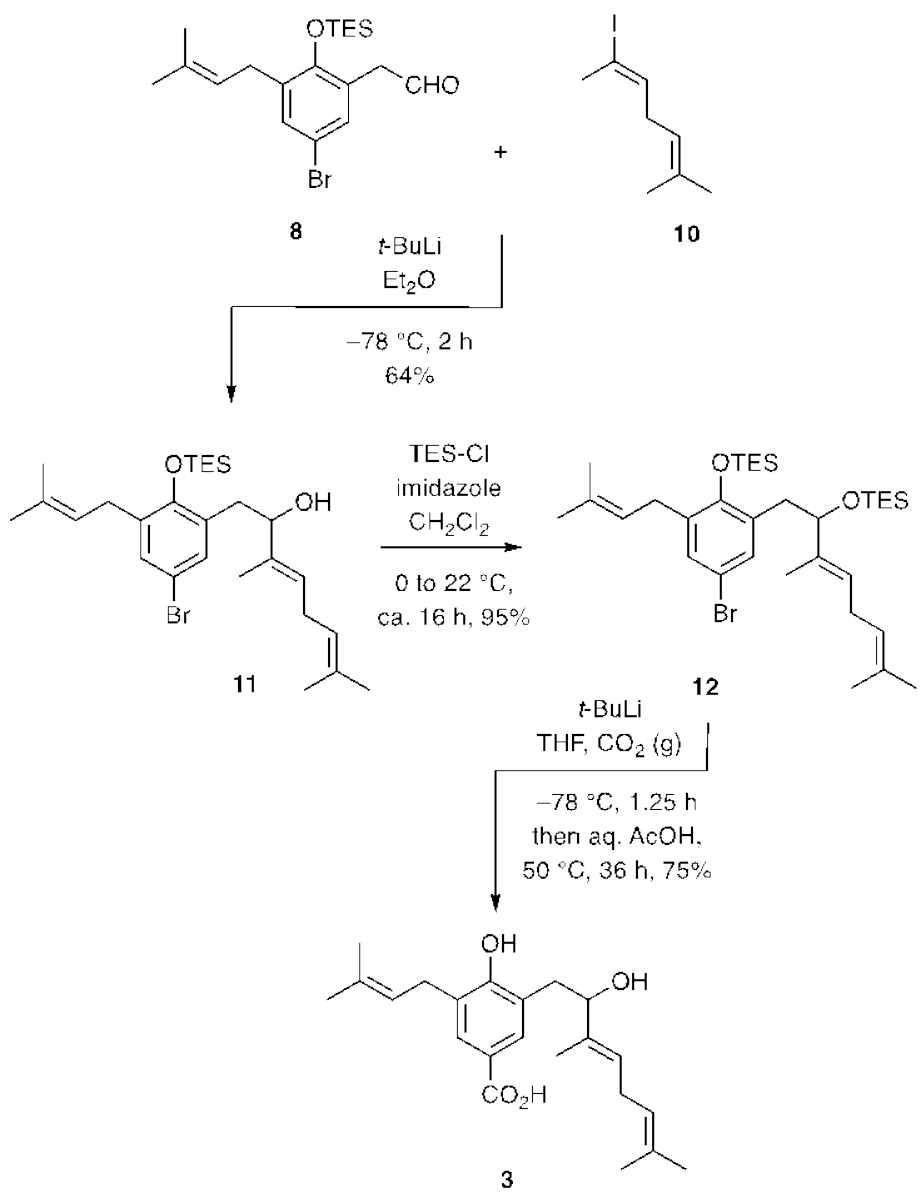

The spectral data derived from acid $\mathbf{3}$ were in complete accord with the assigned structure. Of particular note, the $70 \mathrm{eV}$ electron-impact mass spectrum of this compound did not display a molecular ion at $\mathrm{m} / \mathrm{z}$ 358. In contrast, in the ESI mass spectrum (run in negative mode) a molecular-associated ion was observed at $\mathrm{m} / \mathrm{z} 357$. Furthermore, comparisons of the ${ }^{1} \mathrm{H}$ and ${ }^{13} \mathrm{C}$ NMR spectral data sets derived from the synthetic material proved to be excellent matches with those reported ${ }^{1}$ for MA-F (see Tables 1 and 2). The only notable differences between the two data sets centered on the chemical shifts of the resonances due to the carboxylic acid group carbons $\left(\delta_{\mathrm{C}} 172.5\right.$ for $3 v \mathrm{vs} 170.9$ reported for MA-F), a feature that can be attributed to minor variations in the $\mathrm{pH}$ of the media in which the two data sets were acquired. 
Table 1: Comparison of the ${ }^{1} \mathrm{H}$ NMR Spectral Data Recorded for Compound 3 with those Reported ${ }^{12}$ for Myrsinoic Acid F (MA-F)

\begin{tabular}{|c|c|}
\hline $\begin{array}{c}\text { Compound } 3 \\
\delta_{H^{a, b}}\end{array}$ & $\begin{array}{c}\text { MA-F } \\
\delta_{H}{ }^{b, c}\end{array}$ \\
\hline $\begin{array}{c}7.80 \\
(\mathrm{~d}, J=2.1 \mathrm{~Hz}, 1 \mathrm{H})\end{array}$ & $\begin{array}{c}7.77 \\
(\mathrm{~s}, 1 \mathrm{H})\end{array}$ \\
\hline $\begin{array}{c}7.68 \\
(\mathrm{~d}, J=2.1 \mathrm{~Hz}, 1 \mathrm{H})\end{array}$ & $\begin{array}{c}7.67 \\
(\mathrm{~s}, 1 \mathrm{H})\end{array}$ \\
\hline $\begin{array}{c}5.42 \\
(\mathrm{~m}, 1 \mathrm{H})\end{array}$ & $\begin{array}{c}5.42 \\
(\mathrm{t}, J=6.2 \mathrm{~Hz}, 1 \mathrm{H})\end{array}$ \\
\hline $\begin{array}{c}5.33 \\
(\mathrm{~m}, 1 \mathrm{H})\end{array}$ & $\begin{array}{c}5.34 \\
\text { (broad s, 1H) }\end{array}$ \\
\hline $\begin{array}{c}5.03 \\
(\mathrm{~m}, 1 \mathrm{H})\end{array}$ & $\begin{aligned} & 5.04 \\
(\mathrm{t}, J= & 6.8 \mathrm{~Hz}, 1 \mathrm{H})\end{aligned}$ \\
\hline $\begin{array}{c}4.35 \\
(\mathrm{~d}, J=8.8 \mathrm{~Hz}, 1 \mathrm{H})\end{array}$ & $\begin{aligned} & 4.35 \\
(\mathrm{~d}, J= & 8.5 \mathrm{~Hz}, 1 \mathrm{H})\end{aligned}$ \\
\hline $\begin{array}{c}3.38 \\
(\mathrm{~d}, J=7.3 \mathrm{~Hz}, 2 \mathrm{H})\end{array}$ & $\begin{aligned} & 3.37 \\
(\mathrm{~d}, J= & 6.5 \mathrm{~Hz}, 2 \mathrm{H})\end{aligned}$ \\
\hline $\begin{array}{c}3.04 \\
(\mathrm{dd}, J=14.7,9.1 \mathrm{~Hz}, \\
1 \mathrm{H})\end{array}$ & $\begin{array}{c}3.03 \\
(\mathrm{dd}, J=14.2,9.3 \mathrm{~Hz}, \\
1 \mathrm{H})\end{array}$ \\
\hline $\begin{array}{c}2.76 \\
(\mathrm{~d}, J=14.7 \mathrm{~Hz}, 1 \mathrm{H})\end{array}$ & $\begin{array}{c}2.76 \\
(\mathrm{~d}, J=14.2 \mathrm{~Hz}, 1 \mathrm{H})\end{array}$ \\
\hline $\begin{aligned} & 2.71 \\
(\mathrm{t}, J & =7.3 \mathrm{~Hz}, 2 \mathrm{H})\end{aligned}$ & $\begin{aligned} & 2.71 \\
(\mathrm{t}, J= & 6.8 \mathrm{~Hz}, 2 \mathrm{H})\end{aligned}$ \\
\hline $\begin{array}{c}1.76 \\
(\mathrm{~s}, 3 \mathrm{H})\end{array}$ & $\begin{array}{c}1.75 \\
(\mathrm{~s}, 3 \mathrm{H})\end{array}$ \\
\hline $\begin{array}{c}1.74 \\
(\mathrm{~s}, 3 \mathrm{H})\end{array}$ & $\begin{array}{c}1.73 \\
(\mathrm{~s}, 6 \mathrm{H})\end{array}$ \\
\hline $\begin{array}{c}1.73 \\
(\mathrm{~s}, 3 \mathrm{H})\end{array}$ & - \\
\hline $\begin{array}{l}1.69 \\
(\mathrm{~s}, 3 \mathrm{H})\end{array}$ & $\begin{array}{c}1.69 \\
(\mathrm{~s}, 3 \mathrm{H})\end{array}$ \\
\hline $\begin{array}{c}1.62 \\
(\mathrm{~s}, 3 \mathrm{H})\end{array}$ & $\begin{array}{c}1.62 \\
(\mathrm{~s}, 3 \mathrm{H})\end{array}$ \\
\hline
\end{tabular}

${ }^{a}$ Spectrum recorded in $\mathrm{CDCl}_{3}$ at $400 \mathrm{MHz}$;

${ }^{\mathrm{b}}$ Signals due to the carboxylic acid and hydroxyl group protons not observed;

${ }^{\mathrm{c}}$ Spectrum recorded in $\mathrm{CDCl}_{3}$ at $500 \mathrm{MHz}$. 
Table 2: Comparison of the ${ }^{13} \mathrm{C}$ NMR Chemical Shifts Recorded for Compound $\mathbf{3}$ with those Reported ${ }^{1}$ for Myrsinoic Acid F (MA-F)

\begin{tabular}{|c|c|c|}
\hline $\begin{array}{c}\text { Compound 3 } \\
\delta \mathrm{C}^{\mathrm{a}}\end{array}$ & $\begin{array}{c}\text { MA-F } \\
\delta \mathrm{C}^{\mathrm{b}}\end{array}$ & $\Delta \delta$ \\
\hline 172.5 & 170.9 & +1.6 \\
\hline 159.2 & 159.0 & +0.2 \\
\hline 136.1 & 136.0 & +0.1 \\
\hline 133.4 & 133.2 & +0.2 \\
\hline 132.5 & 132.4 & +0.1 \\
\hline 131.9 & 131.8 & +0.1 \\
\hline 131.0 & 130.9 & +0.1 \\
\hline 129.9 & 129.8 & +0.1 \\
\hline 125.9 & 125.8 & +0.1 \\
\hline 125.8 & 125.6 & +0.2 \\
\hline $122.1(0)$ & 122.0 & +0.1 \\
\hline $122.0(6)$ & 121.9 & +0.2 \\
\hline 120.7 & 120.4 & +0.3 \\
\hline 80.2 & 80.2 & 0 \\
\hline 38.5 & 38.4 & +0.1 \\
\hline 28.9 & 28.8 & +0.1 \\
\hline 26.7 & 26.6 & +0.1 \\
\hline 26.0 & 25.8 & +0.2 \\
\hline 25.8 & 25.7 & +0.1 \\
\hline 18.0 & 17.9 & +0.1 \\
\hline 17.9 & 17.7 & +0.2 \\
\hline 12.2 & 12.1 & +0.1 \\
\hline
\end{tabular}

a Spectrum recorded in $\mathrm{CDCl}_{3}$ at $100 \mathrm{MHz}$;

b Spectrum recorded in $\mathrm{CDCl}_{3}$ at $125 \mathrm{MHz}$. 
In order to assist with the development of a structure-activity relationship profile for MAF related compounds, the mono-ether $\mathbf{1 1}$ was subjected to desilylation by treating a THF solution of it with the aqueous acetic acid at $50{ }^{\circ} \mathrm{C}$ for $18 \mathrm{~h}$ (Scheme 4) and thereby forming the previously reported ${ }^{4}$ bromo-analogue, $\mathbf{1 3}$ (80\%), of compound $\mathbf{3}$. All the spectral data derived from this product were in complete accord with the illustrated structure and matched those recorded previously. ${ }^{4}$

Scheme 4: Synthesis of the Bromo-analogue, 13, of Myrsinoic Acid F

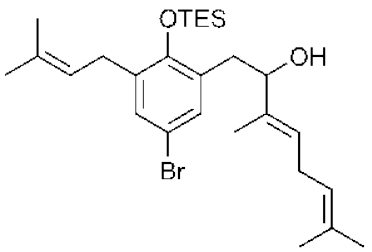

11

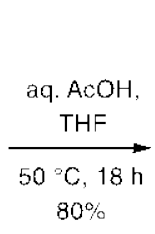

$80 \%$

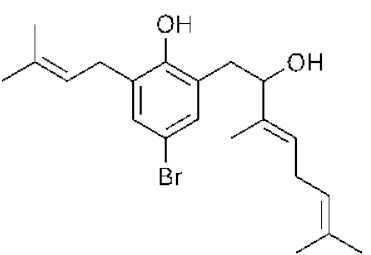

13 


\section{Biological Studies}

With significant quantities of the synthetically derived compounds 3, 7, 8, 12 and 13 to hand each of these was subjected to evaluation in the same mouse ear edema assay used to evaluate the anti-inflammatory properties of compounds $\mathbf{1}$ and $2 .{ }^{4}$ These tests revealed, as shown in Table 3, that MA-F (3) is a significantly more potent anti-inflammatory agent than the widely prescribed NSAID indometacin and even more active than its cyclic congener 1 (that showed ${ }^{4}$ activities similar to indometacin in the same assay). Similarly, the bromo-analogue $\mathbf{1 3}$ displayed significant anti-inflammatory effects while the structurally simpler congeners also possessed some activity. The perhaps counterintuitive observation that the less concentrated samples of certain of the test compounds showed greater inhibition rates is not uncommon in animal tests and could also be attributed, in relevant cases, to partial cleavage of the associated TES-ether moiety under the assay conditions.

Table 3: Outcomes of the biological evaluation of compounds 3, 7, 8, 12 and 13 in a TPA-induced mouse ear edema assay ${ }^{\dagger}$

$\begin{array}{ccc}\text { compound } & \begin{array}{c}\text { concentration } \\ (\mu \mathrm{M})\end{array} & \text { inhibition rate (\%) } \\ \text { blank } & - & 0 \\ \text { indometacin } & 0.56 & 31.5 \\ \text { indometacin } & 1.4 & 30.2 \\ \mathbf{3} & 0.56 & 55.0 \\ \mathbf{3} & 1.4 & 68.9 \\ \mathbf{7} & 0.56 & 27.5 \\ \mathbf{7} & 1.4 & 31.5 \\ \mathbf{8} & 0.56 & 36.0 \\ \mathbf{8} & 1.4 & 32.0 \\ \mathbf{1 2} & 0.56 & 41.4 \\ \mathbf{1 2} & 1.4 & 31.8 \\ \mathbf{1 3} & 0.56 & 43.7 \\ \mathbf{1 3} & 1.4 & 38.3\end{array}$

${ }^{\dagger}$ A sample ( 0.56 or $\left.1.4 \mu \mathrm{M}\right)$ of the test compound was applied to one mouse ear and, after $0.5 \mathrm{~h}$, TPA ( 0.5 $\square \mathrm{g}$ ) was applied to both ears of the mouse. The edema was evaluated after $7 \mathrm{~h}$, the cited inhibition rate being determined as detailed in the SI. Five mice were used for each experiment. 


\section{CONCLUSIONS}

The studies reported herein serve to establish the true structure, $\mathbf{3}$, of the potent antiinflammatory natural product myrsinoic acid $\mathrm{F}$ and provide a rational basis for the original misassignment of it as the dihydrobenzofuran 1. The synthetic sequences established in the course of both the present and earlier ${ }^{4}$ studies are likely to provide effective means for accessing other members of myrsinoic acid class of natural product as well as various analogues. They should also enable syntheses of related and biologically active natural products such as the amorfrutins. ${ }^{9}$ 


\section{EXPERIMENTAL SECTION}

\section{General Experimental Procedures.}

Unless otherwise specified, proton $\left({ }^{1} \mathrm{H}\right)$ and carbon $\left({ }^{13} \mathrm{C}\right)$ NMR spectra were recorded at room temperature in base-filtered $\mathrm{CDCl}_{3}$ on a Bruker spectrometer operating at $400 \mathrm{MHz}$ for proton and $100 \mathrm{MHz}$ for carbon nuclei. The signal due to residual $\mathrm{CHCl}_{3}$ appearing at $\delta_{\mathrm{H}} 7.26$ and the central resonance of the $\mathrm{CDCl}_{3}$ triplet appearing at $\delta_{\mathrm{C}} 77.1(6)$ were used to reference ${ }^{1} \mathrm{H}$ and ${ }^{13} \mathrm{C}$ NMR spectra, respectively. ${ }^{1} \mathrm{H}$ NMR data are recorded as follows: chemical shift $(\delta)$ [multiplicity, coupling constant(s) $J(\mathrm{~Hz})$, relative integral] where multiplicity is defined as: $\mathrm{s}=$ singlet; $\mathrm{d}=$ doublet; $\mathrm{t}=$ triplet; $\mathrm{q}=$ quartet; $\mathrm{m}=$ multiplet or combinations of the above. IR spectra were recorded, using neat samples, on an attenuated total reflectance (ATR) infrared spectrometer. Samples were analyzed as either thin films or finely divided solids. Low-resolution ESI mass spectra were recorded on a single quadrupole mass spectrometer, while high-resolution measurements were conducted on a time-of-flight instrument. Low- and high-resolution EI mass spectra were recorded on a magnetic-sector machine. Analytical thin layer chromatography (TLC) was performed on aluminum-backed $0.2 \mathrm{~mm}$ thick silica gel $60 \mathrm{~F}_{254}$ plates as supplied by Merck. Eluted plates were visualized using a $254 \mathrm{~nm}$ UV lamp and/or by treatment with a suitable dip followed by heating. These dips included phosphomolybdic acid : ceric sulfate : sulfuric acid (conc.) : water (37.5 g : $7.5 \mathrm{~g}: 37.5 \mathrm{~g}: 720 \mathrm{~mL}$ ) or potassium permanganate : potassium carbonate : $5 \%$ sodium hydroxide aqueous solution : water (3 g : 20 g: $5 \mathrm{~mL}$ : $300 \mathrm{~mL}$ ). Flash chromatographic separations were carried out following protocols defined by Still et al. ${ }^{10}$ with silica gel $60(40-63 \mu \mathrm{m})$ as the stationary phase and using the AR- or HPLC-grade solvents indicated. Starting materials and reagents were generally available from the Sigma-Aldrich, Merck, TCI, Strem or Lancaster Chemical Companies and were used as supplied. Drying agents and other inorganic salts were purchased from the AJAX, BDH or Unilab Chemical Companies. Tetrahydrofuran (THF), methanol and dichloromethane were dried using a Glass Contour solvent purification system that is based upon a technology originally described by Grubbs et al. ${ }^{11}$ Where necessary, reactions were performed under an nitrogen atmosphere. 


\section{Specific Chemical Transformations}

\section{(E)-(4-Bromo-2-(2-methoxyvinyl)-6-(3-methylbut-2-en-1-yl)phenoxy)triethylsilane}

(7). A magnetically stirred suspension of methoxymethyltriphenylphosphonium chloride (7.64 g, $22.3 \mathrm{mmol})$ in dry THF $(150 \mathrm{~mL})$ was cooled to $-40{ }^{\circ} \mathrm{C}$ then treated with a solution of $t$-BuOK (3.76 g, $33.5 \mathrm{mmol})$ in dry THF (30 mL). The ensuing mixture was maintained at this temperature for $0.3 \mathrm{~h}$ and the resulting dark-red reaction mixture treated with a solution of benzaldehyde $6^{4}$ (2.79 g, $\left.10.4 \mathrm{mmol}\right)$ in dry THF (30 mL) before being warmed to $0{ }^{\circ} \mathrm{C}$, stirred at this temperature for $1 \mathrm{~h}$, treated with TES-Cl (4.45 mL, $26.5 \mathrm{mmol})$, stirred at $0{ }^{\circ} \mathrm{C}$ for $1 \mathrm{~h}$ then treated with $\mathrm{NH}_{4} \mathrm{Cl}(100 \mathrm{~mL}$ of a saturated aqueous solution) and extracted with ethyl acetate $(3 \times 100 \mathrm{~mL})$. The combined organic phases were dried $\left(\mathrm{Na}_{2} \mathrm{SO}_{4}\right)$, filtered and concentrated under reduced pressure and the residue thus obtained subjected to flash chromatography (silica, 95:5 v/v hexanes/toluene elution). Concentration of the appropriate fractions $\left(R_{f}=0.9\right.$ in 9:1 v/v hexanes/ethyl acetate) afforded enol ether 7 (2.86 g, 67\%) as a clear, light-yellow oil. ${ }^{1} \mathrm{H}$ NMR (400 MHz, $\left.\mathrm{CDCl}_{3}\right) \delta 7.93(\mathrm{~d}, J=2.6 \mathrm{~Hz}, 1 \mathrm{H}), 7.01$ (d, $\left.J=2.6 \mathrm{~Hz}, 1 \mathrm{H}\right), 6.17$ (d, $J=$ $7.2 \mathrm{~Hz}, 1 \mathrm{H}), 5.39$ (d, $J=7.2 \mathrm{~Hz}, 1 \mathrm{H}), 5.25$ (m, 1H), 3.77 (s, 3H), 3.24 (d, $J=7.2 \mathrm{~Hz}$, 2H), 1.77 (s, 3H), 1.67 (s, 3H), 0.96 (t, $J=7.9 \mathrm{~Hz}, 9 \mathrm{H}), 0.75$ (q, $J=7.9 \mathrm{~Hz}, 6 \mathrm{H}$ ); ${ }^{13} \mathrm{C}$ NMR (100 MHz, $\left.\mathrm{CDCl}_{3}\right) \delta 149.6,148.4,134.0,133.7,129.9,129.6,129.2,121.9,114.2$, 99.9, 60.9, 28.8, 25.9, 18.0, 6.9, 5.8; IR (ATR) $v_{\max }$ 2957, 2913, 1648, 1433, 1262, 1096, 1004, 907, 822, $740 \mathrm{~cm}^{-1}$; MS (ESI, +ve) $\mathrm{m} / \mathrm{z}(\%) 435$ and $433[\mathrm{M}+\mathrm{Na}]^{+}$(100 and 92), 413 (18), 332 (20), 147 (19); HRMS (TOF ESI, +ve) m/z 433.1171 [M+Na] ${ }^{+}$(calcd for $\left.\mathrm{C}_{20} \mathrm{H}_{31}{ }^{79} \mathrm{BrO}_{2} \mathrm{SiNa}, 433.1174\right)$.

2-(5-Bromo-3-(3-methylbut-2-en-1-yl)-2-((triethylsilyl)oxy)phenyl)acetaldehyde (8). A magnetically stirred solution of enol ether 7 (370 mg, $0.90 \mathrm{mmol})$ in $\mathrm{CH}_{2} \mathrm{Cl}_{2}(10 \mathrm{~mL}$ ) containing water $(50 \mu \mathrm{L})$ was treated with TFA $(250 \mu \mathrm{L}, 3.26 \mathrm{mmol})$ then maintained at $22{ }^{\circ} \mathrm{C}$ for $0.5 \mathrm{~h}$. The resulting mixture was quenched with $\mathrm{NaHCO}_{3}(10 \mathrm{~mL}$ of a saturated aqueous solution) before being extracted with $\mathrm{CH}_{2} \mathrm{Cl}_{2}(3 \times 15 \mathrm{~mL})$. The combined organic phases were dried $\left(\mathrm{Na}_{2} \mathrm{SO}_{4}\right)$, filtered and concentrated under reduced pressure and the residue thus obtained subjected to flash chromatography (silica, 99:1 $\rightarrow$ 95:5 v/v hexanes/ethyl acetate elution) to afford, after concentration of the appropriate fractions ( $R_{f}=0.8$ in 9:1 v/v hexanes/ethyl acetate), aldehyde 8 (337 mg, 94\%) as a clear, colorless 
oil. ${ }^{1} \mathrm{H}$ NMR (400 MHz, $\mathrm{CDCl}_{3}$ ) $\delta 9.65$ (t, $\left.J=2.1 \mathrm{~Hz}, 1 \mathrm{H}\right), 7.17$ (d, $J=2.6 \mathrm{~Hz}, 1 \mathrm{H}$ ), 7.10 (d, $J=2.6 \mathrm{~Hz}, 1 \mathrm{H}$ ), 5.26 (m, 1H), 3.59 (d, $J=2.1 \mathrm{~Hz}, 2 \mathrm{H}$ ), 3.27 (d, $J=7.3 \mathrm{~Hz}, 2 \mathrm{H}), 1.79$ (s, 3H), 1.68 (s, 3H), 0.96 (t, $J=7.8 \mathrm{~Hz}, 9 \mathrm{H}), 0.75$ (q, $J=7.8 \mathrm{~Hz}, 6 \mathrm{H}) ;{ }^{13} \mathrm{C}$ NMR (100 $\left.\mathrm{MHz}, \mathrm{CDCl}_{3}\right) \delta 199.4,151.9,135.0,134.5,131.8,131.4,125.4,121.3,114.4,45.6,28.8$, 25.9, 18.0, 6.9, 5.8; IR (ATR) $v_{\max } 2958,1728,1455,1271,1200,1006,911,817,742$ $\mathrm{cm}^{-1}$; MS (ESI, +ve) m/z (\%) 453 and $451[\mathrm{M}+\mathrm{Na}+\mathrm{MeOH}]^{+}$(100 and 95), 399 and 397 $[\mathrm{M}+\mathrm{H}]^{+}$(both <1), 373 (18), 301 (10), 147 (7); HRMS (TOF ESI, +ve) m/z 397.1194 $[\mathrm{M}+\mathrm{H}]^{+}$(calcd for $\mathrm{C}_{19} \mathrm{H}_{30}{ }^{79} \mathrm{BrO}_{2} \mathrm{Si}$, 397.1193).

(E)-2-Iodo-6-methylhepta-2,5-diene (10). A magnetically stirred solution of hydrazone $\mathbf{9}^{4}$ (2.00 g, $\left.5.91 \mathrm{mmol}\right)$ in THF (30 mL) was cooled to $-78{ }^{\circ} \mathrm{C}$ then treated with $n$-BuLi (5.33 $\mathrm{mL}$ of $2.38 \mathrm{M}$ solution in hexane, $12.7 \mathrm{mmol}$ ). The resulting orange solution was stirred at $-78{ }^{\circ} \mathrm{C}$ for $1 \mathrm{~h}$ then treated, dropwise, with prenyl bromide (820 $\mu \mathrm{L}, 7.11$ mmol). The yellow solution thus obtained was allowed to warm to $-60{ }^{\circ} \mathrm{C}$ over $1 \mathrm{~h}$ then re-cooled to $-78{ }^{\circ} \mathrm{C}$ and treated with $n$-BuLi $(2.70 \mathrm{~mL}$ of $2.38 \mathrm{M}$ solution in hexane, 6.43 mmol). The solution turned an orange color and was stirred at $-78{ }^{\circ} \mathrm{C}$ for $0.25 \mathrm{~h}$ then warmed to $0{ }^{\circ} \mathrm{C}$, maintained at this temperature for $0.5 \mathrm{~h}$ and during which time gas evolution was observed. The reaction was then re-cooled to $-78{ }^{\circ} \mathrm{C}$ and treated with $1,2-$ di-iodoethane (2.08 g, $7.40 \mathrm{mmol})$. After $0.3 \mathrm{~h}$ at $-78{ }^{\circ} \mathrm{C}$ the reaction mixture was warmed to $22{ }^{\circ} \mathrm{C}$, stirred at this temperature for $0.5 \mathrm{~h}$ then treated with $\mathrm{Na}_{2} \mathrm{~S}_{2} \mathrm{O}_{3}(50 \mathrm{~mL}$ of a saturated aqueous solution) before being extracted with ethyl acetate $(3 \times 100 \mathrm{~mL})$. The combined organic phases were dried $\left(\mathrm{Na}_{2} \mathrm{SO}_{4}\right)$, filtered and concentrated under reduced pressure. The residue thus obtained was subjected to flash chromatography (silica, cyclohexane elution) to afford, after concentration of the appropriate fractions ( $R_{f}$ $=0.9$ in hexanes), iodide $\mathbf{1 0}^{4}(1.27 \mathrm{~g}, 91 \%)$ as a clear, pink-orange and light-sensitive oil. ${ }^{1} \mathrm{H}$ NMR (400 MHz, $\left.\mathrm{CDCl}_{3}\right) \delta 6.11$ (m, 1H), 5.07 (m, 1H), 2.70 (t, $\left.J=7.5 \mathrm{~Hz}, 2 \mathrm{H}\right), 2.39$ (s, 3H), 1.69 (s, 3H), 1.61 (s, 3H); ${ }^{13} \mathrm{C}$ NMR (100 MHz, $\left.\mathrm{CDCl}_{3}\right) \delta 139.9,133.2,120.1$, 93.6, 29.8, 27.6, 25.8, 17.9. This material was identical, in all respects, with a sample prepared as described ${ }^{4}$ earlier.

(E)-1-(5-Bromo-3-(3-methylbut-2-en-1-yl)-2-((triethylsilyl)oxy)phenyl)-3,7-dimethylocta-3,6-dien-2-ol (11). A magnetically stirred solution of iodide 10 (1.00 g, $4.24 \mathrm{mmol})$ in dry diethyl ether $\left(20 \mathrm{~mL}\right.$ ) was cooled to $-78{ }^{\circ} \mathrm{C}$, treated, dropwise, with $t$-BuLi (3.67 
$\mathrm{mL}$ of a $1.5 \mathrm{M}$ solution in hexanes, $5.51 \mathrm{mmol}$ ), maintained at this temperature for $1 \mathrm{~h}$ then treated with a solution of aldehyde 8 (1.12 g, $2.82 \mathrm{mmol})$ in dry diethyl ether (5 $\mathrm{mL}$ ). The ensuing mixture was maintained at $-78{ }^{\circ} \mathrm{C}$ for $1 \mathrm{~h}$ before being diluted with brine $(20 \mathrm{~mL})$ then, after warming, extracted with ethyl acetate $(3 \times 15 \mathrm{~mL})$. The combined organic phases were dried $\left(\mathrm{Na}_{2} \mathrm{SO}_{4}\right)$, filtered and concentrated under reduced pressure and the residue thus obtained subjected to flash chromatography (silica, 98:2 $\rightarrow$ 95:5 v/v hexanes/ethyl acetate elution). Concentration of the appropriate fractions $\left(R_{f}=\right.$ 0.4 in 9:1 v/v hexanes/ethyl acetate) then gave compound 11 (1.11 g, 64\%) as a lightyellow oil. ${ }^{1} \mathrm{H}$ NMR (400 MHz, $\left.\mathrm{CDCl}_{3}\right) \delta 7.13(\mathrm{~d}, J=2.6 \mathrm{~Hz}, 1 \mathrm{H}), 7.07$ (d, $J=2.6 \mathrm{~Hz}$, 1H), 5.36 (t, $J=7.3 \mathrm{~Hz}, 1 \mathrm{H}), 5.24$ (m, 1H), 5.05 (m, 1H), 4.21 (m, 1H), 3.25 (d, $J=7.3$ Hz, 2H), 2.82 (dd, $J=13.8$ and $8.7 \mathrm{~Hz}, 1 \mathrm{H}$ ), 2.75-2.67 (complex m, 3H), 1.79 (m, 1H), 1.78 (s, 3H), 1.70 (s, 3H), 1.69 (s, 3H), 1.67 (s, 3H), 1.62 (s, 3H), 0.96 (t, J = 7.9 Hz, 9H), 0.76 (q, $J=7.9 \mathrm{~Hz}, 6 \mathrm{H}) ;{ }^{13} \mathrm{C}$ NMR (100 MHz, $\left.\mathrm{CDCl}_{3}\right) \delta 151.7,136.4,134.5,134.1$, 132.0, 131.7, 131.2, 130.5, 126.1, 122.6, 121.7, 114.2, 77.6, 37.3, 28.9, 26.8, 25.9, 25.8, 18.0, 17.9, 11.7, 6.9, 5.8; IR (ATR) $v_{\max }$ 3391, 2958, 2913, 2877, 1452, 1267, 1198, 910, 816, $739 \mathrm{~cm}^{-1}$; MS (ESI, +ve) m/z (\%) 531 and $529[\mathrm{M}+\mathrm{Na}]^{+}$(73 and 70), 130 (100), 88 (14); HRMS (TOF ESI, +ve) $\mathrm{m} / \mathrm{z} 529.2113[\mathrm{M}+\mathrm{Na}]^{+}$(calcd for $\mathrm{C}_{27} \mathrm{H}_{43}{ }^{79} \mathrm{BrO}_{2} \mathrm{SiNa}$ 529.2113).

\section{(E)-(4-Bromo-2-(3,7-dimethyl-2-((triethylsilyl)oxy)octa-3,6-dien-1-yl)-6-(3-methyl-}

but-2-en-1-yl)phenoxy)triethylsilane (12). A magnetically stirred solution of compound 11 (430 mg, $0.85 \mathrm{mmol}$ ) and imidazole (157 mg, $2.30 \mathrm{mmol}$ ) in $\mathrm{CH}_{2} \mathrm{Cl}_{2}$ (15 mL) was cooled to $0{ }^{\circ} \mathrm{C}$ then treated with TES-Cl $(0.31 \mathrm{~mL}, 1.82 \mathrm{~mL})$. The resulting solution was allowed to warm to $22{ }^{\circ} \mathrm{C}$, stirred at this temperature for $16 \mathrm{~h}$ then treated with $\mathrm{NaHCO}_{3}$ (10 mL of a saturated aqueous solution) and extracted with ethyl acetate $(3 \times 15 \mathrm{~mL})$. The combined organic phases were dried $\left(\mathrm{Na}_{2} \mathrm{SO}_{4}\right)$, filtered and concentrated under reduced pressure and the residue thus obtained subjected to flash chromatography (silica, hexanes $\rightarrow$ 95:5 v/v hexanes/ethyl acetate elution). Concentration of the appropriate fractions $\left(R_{f}=0.9\right.$ in 9:1 v/v hexanes/ethyl acetate) afforded compound 12 (499 mg, 95\%) as a clear, light-yellow oil. ${ }^{1} \mathrm{H}$ NMR (400 MHz, $\left.\mathrm{CDCl}_{3}\right) \delta 7.12$ (d, $\left.J=2.6 \mathrm{~Hz}, 1 \mathrm{H}\right)$, 7.02 (d, $J=2.6 \mathrm{~Hz}, 1 \mathrm{H}), 5.24$ (m, 2H), 5.05 (m, 1H), 4.14 (m, 1H), 3.23 (m, 2H), 2.732.55 (complex m, 4H), 1.77 (s, 3H), 1.69 (s, 3H), 1.67 (s, 3H), 1.66 (s, 3H), 1.62 (s, 3H), 
0.94 (t, $J=7.9 \mathrm{~Hz}, 9 \mathrm{H}$ ), 0.82-0.68 (complex m, 15H), 0.46-0.27 (complex m, 6H); ${ }^{13} \mathrm{C}$ NMR (100 MHz, $\left.\mathrm{CDCl}_{3}\right) \delta 151.5,137.4,134.1,133.6,132.4,132.1,131.8,129.8,125.0$, 122.7, 122.1, 113.6, 78.2, 38.1, 28.9, 26.7, 25.9, 25.8, 18.0, 17.8, 11.1, 7.0, 6.9, 5.8, 4.8; IR (ATR) $v_{\max }$ 2956, 2912, 2877, 1455, 1270, 1200, 1065, 1004, 812, $740 \mathrm{~cm}^{-1}$; MS (ESI, +ve) $\mathrm{m} / \mathrm{z}(\%) 645$ and $643[\mathrm{M}+\mathrm{Na}]^{+}$(100 and 90), 121 (10); HRMS (TOF ESI, +ve) $\mathrm{m} / \mathrm{z}$ 643.2974 [M+Na] ${ }^{+}$(calcd for $\mathrm{C}_{33} \mathrm{H}_{57}{ }^{79} \mathrm{BrO}_{2} \mathrm{Si}_{2} \mathrm{Na}, 643.2978$ ).

(E)-4-Hydroxy-3-(2-hydroxy-3,7-dimethylocta-3,6-dien-1-yl)-5-(3-methylbut-2-en-1yl)benzoic acid (3). A magnetically stirred solution of compound 12 (200 mg, 0.32 $\mathrm{mmol})$ in THF $(5 \mathrm{~mL})$ was cooled to $-78{ }^{\circ} \mathrm{C}$ then treated with $t$-BuLi $(0.53 \mathrm{~mL}$ of $1.5 \mathrm{M}$ solution in hexanes, $0.80 \mathrm{mmol}$ ). The resulting yellow solution was stirred at $-78{ }^{\circ} \mathrm{C}$ for $0.75 \mathrm{~h}$ then dry $\mathrm{CO}_{2}(\mathrm{~g})$ was bubbled into the reaction mixture for $0.5 \mathrm{~h}$. The resulting clear, colorless solution was treated with acetic acid $(2 \mathrm{~mL}$ of a $50 \% \mathrm{v} / \mathrm{v}$ aqueous solution), heated at $50{ }^{\circ} \mathrm{C}$ for $36 \mathrm{~h}$ before being cooled to $22^{\circ} \mathrm{C}$ then treated with TLCgrade silica gel (500 mg) and concentrated under reduced pressure. The resulting freeflowing powder was subjected to flash chromatography (silica, 8:2 $\rightarrow$ 1:1 v/v hexanes/ethyl acetate elution) to afford, after concentration of the appropriate fractions ( $R_{f}=0.5$ in 3:2 v/v hexanes/ethyl acetate), carboxylic acid 3 (86 mg, 75\%) as a clear, light-yellow oil. ${ }^{1} \mathrm{H}$ NMR (400 MHz, $\left.\mathrm{CDCl}_{3}\right) \delta$ see Table $1 ;{ }^{13} \mathrm{C} \mathrm{NMR}\left(100 \mathrm{MHz}, \mathrm{CDCl}_{3}\right)$ $\delta$ see Table 2; IR (ATR) $v_{\max }$ 2965, 2915, 1679, 1600, 1408, 1263, 1214, $776 \mathrm{~cm}^{-1}$; MS (ESI, -ve) m/z (\%) 357 [M-H] $]^{-}$(100), 101 (71), 62 (21); HRMS (TOF ESI, -ve) m/z 357.2051 [M-H] $]^{-}$(calcd for $\mathrm{C}_{22} \mathrm{H}_{29} \mathrm{O}_{4}, 357.2060$ ).

(E)-4-Bromo-2-(2-hydroxy-3,7-dimethylocta-3,6-dien-1-yl)-6-(3-methylbut-2-en-1-yl) -phenol (13). A magnetically stirred solution of allylic alcohol 11 (100 mg, $0.20 \mathrm{mmol}$ ) in THF (2 mL) was treated with acetic acid/water (2 $\mathrm{mL}$ of a 1:1 v/v aqueous solution) and the resulting mixture heated at $50{ }^{\circ} \mathrm{C}$ for $18 \mathrm{~h}$ then cooled and treated with $\mathrm{NaHCO}_{3}$ ( $5 \mathrm{~mL}$ of a saturated aqueous solution) before being extracted with ethyl acetate $(3 \times 20$ $\mathrm{mL})$. The combined organic phases were dried $\left(\mathrm{Na}_{2} \mathrm{SO}_{4}\right)$, filtered and concentrated under reducer pressure. The residue thus obtained was subjected to flash chromatography (silica, 95:5 v/v hexanes/ethyl acetate elution) to afford, after concentration of the appropriate fractions ( $R_{f}=0.8 \mathrm{in} 9: 1 \mathrm{v} / \mathrm{v}$ hexanes/ethyl acetate), diol 13 (63 mg, 80\%) as a light-yellow oil. ${ }^{1} \mathrm{H}$ NMR (400 MHz, $\left.\mathrm{CDCl}_{3}\right) \delta 8.18$ (s, 1H), 7.11 (d, $\left.J=2.5 \mathrm{~Hz}, 1 \mathrm{H}\right)$, 
7.01 (d, $J=2.5 \mathrm{~Hz}, 1 \mathrm{H}), 5.41$ (m, 1H), 5.29 (m, 1H), 5.05 (m, 1H), 4.30 (d, $J=9.3 \mathrm{~Hz}$, 1H), 3.32 (d, $J=7.3 \mathrm{~Hz}, 2 \mathrm{H}), 2.98$ (m, 1H), 2.71 (t, $J=7.3 \mathrm{~Hz}, 2 \mathrm{H}), 2.61$ (d, $J=14.5 \mathrm{~Hz}$, 1H), 2.30 (s, 1H), $1.76(\mathrm{~s}, 3 \mathrm{H}), 1.71(\mathrm{~m}, 9 \mathrm{H}), 1.63(\mathrm{~s}, 3 \mathrm{H})$. These data matched those recorded on an authentic sample. ${ }^{4}$

Anti-inflammatory Test. The TPA-induced mouse ear edema assay inflammatory tests used in this study were modifications of a protocol defined by Gschwendt ${ }^{12}$ and employed in the original evaluation of myrsinoic acid $\mathrm{F}^{1}$ as well as our recent studies. ${ }^{4}$ Specifically, $20 \mu \mathrm{L}$ solutions of each of compounds 3, 7, 8, 12 and 13 in acetone at concentrations of 1.4 or $0.56 \mu \mathrm{mol}$ were applied to the outer surface of right ears of the mice by means of an automatic microliter pipet. After 0.5 h, 12-O-tetradecanoylphorbol13-acetate (TPA) $(0.5 \mu \mathrm{g}$ in $20 \mu \mathrm{L}$ of acetone) was applied to the right ears of each animal. Blank controls received acetone alone while indometacin served as the positive control. After a further $7 \mathrm{~h}$ the animals were sacrificed and both ears removed. Plugs of $0.8 \mathrm{~cm}$ in diameter were then obtained from the tips of both the right and left ears with the aid of a punch and these were weighed to the nearest $0.1 \mathrm{mg}$. The extent of the edema was determined from the mean difference in weight of right and left ear-plugs ( $\Delta$ weight) and taken to represent the degree of swelling. The inhibition rate (in \% terms) was determined using the following equation:

Inhibition rate $(\%)=(\Delta$ weight of control $-\Delta$ weight of sample/ $\Delta$ weight of control $) \times 100$ 


\section{ASSOCIATED CONTENT}

\section{Supporting Information}

${ }^{1} \mathrm{H}$ and ${ }^{13} \mathrm{C}$ NMR spectra of compounds 3, 7, 8 and 10-13. This material is available freeof-charge via the Internet at http://pubs.acs.org.

\section{AUTHOR INFORMATION}

\section{Corresponding Author}

*Tel: +61-2-6125-8202. Fax: +61-2-6125-8114. E-mail: Martin.Banwell@anu.edu.au

\section{Notes}

The authors declare no competing financial interest.

\section{ACKNOWLEDGMENTS}

We thank the Australian Research Council, the Institute of Advanced Studies, Jinan University, the Pearl River Scholar Program of Guangdong Province and the Famous Foreign Supervisor Program (Grant 2018-HWMS001) of the Ministry of Education, People’s Republic of China for financial support. The continued interest of Drs Alison Findlay and Jonathan Foot (Pharmaxis Ltd, Sydney, Australia) in this work is gratefully acknowledged. 


\section{REFERENCES AND NOTES}

1. Hirota, M.; Miyazaki, S.; Minakuchi, T.; Takagi, T.; Shibata, H. Biosci. Biotechnol. Biochem. 2002, 66, 655.

2. (a) Amaro-Luis, J. M.; Koteich-Khatib, S.; Carrillo-Rodríguez, F.; Bahsas, A. Nat. Prod. Commun., 2008, 3, 323; (b) Zermiani, T.; Malheiros, A.; Luconda da Silva, R. M.; Stulzer, H. K.; Bresolin, T. M. B. Arabian J. Chem., 2016, 9, 872; (b) Lee, S. W.; Mandinova, A. US Patent 8,232,318 B2, July 31 ${ }^{\text {st }}$ 2012; (c) Ito, S.; Narise, A.; Shimura, S. Biosci. Biotechnol. Biochem. 2008, 72, 2411; (d) Ito, S.; Shimra, S.; Tanaka, T.; Yaegaki, K. J. Breath Res., 2010, 4, 1752; (e) de Melo Burger, M. C.; Terezan, A. P.; de Oliveira Cunha, G. S.; Fernandes, J. B.; da Silva, M. F. das G. F.; Vieira, P. C.; Menezes, A. C. S., Rev. Bras. Farmacogn., 2015, 25, 451; (f) Filho, V. C.; Meyre-Silva, C.; NIero, R.; Mariano, L. N. B.; do Nascimenta, F. G.; Farias, I. V. C.; Gazoni, V. F.; dos Santos Silva, B.; Giménez, A.; Gutierrez-Yapu, D.; Salamanca, E.; Malheiros, A., Evid. Based Complement. Alternat. Med., 2013, Article ID 265025.

3. Mizushina, Y.; Hirota, M.; Murakami, C.; Ishidoh, T.; Kamisuki, S.; Shimazaki, N.; Takemura, M.; Perpelescu, M.; Suzuki, M.; Yoshida, H.; Sugawara, F.; Koiwai, O.; Sakaguchi, K. Biochem. Pharmacol., 2003, 66, 1935.

4. Mikusek, J.; Nugent, J.; Ward, J. S.; Schwartz, B. D.; Findlay, A. D.; Foot, J. S.; Banwell, M. G. Org. Lett. 2018, 20, 3984.

5. We thank a reviewer of our earlier paper for first suggesting this possibility.

6. Sauer, S.; Weidner, C.; Kliem, M.; Schroeder, F. C.; Micikas, R. J. WO 2014/177593 A1, 29 April, 2014.

7. Bates, R. W.; Gabel, C. J. Tetrahedron Lett. 1993, 34, 3547.

8. Chamberlin, A. R.; Liotta, E. L.; Bond, T. T. Org. Synth. 1983, 61, 141.

9. Weidner, C.; Rousseau, M.; Micikas, R. J.; Fischer, C.; Plauth, A.; Wowro, S. J.; Siems, K.; Hetterling, G.; Kliem, M.; Schroeder, F. C.; Sauer, S. J. Nat. Prod. 2016, 79, 2.

10. Still, W. C.; Kahn, M.; Mitra, A. J. Org. Chem. 1978, 43, 2923-2925.

11. Pangborn, A. B.; Giardello, M. A.; Grubbs, R. H.; Rosen, R. K.; Timmers, F. J. Organometallics 1996, 15, 1518-1520.

12. Gschwendt, M.; Kittstein, W.; Furstenberger, G.; Marks, F., Cancer Letters, 1984, 25, 177. 